\title{
STRATEGI MEMBANGUN KECERDASAN MORAL DALAM PEMBELAJARAN BAHASA DI SEKOLAH
}

\section{OLEH: \\ RAHAYU APRILIASWATI ${ }^{1}$}

\begin{abstract}
Abstrak: Maraknya korupsi, penyalahgunaan kekuasaan, kekerasan, dan tindakan yang merugikan orang lain, masyarakat, dan negara menunjukkan pendidikan di Indonesia belum berhasil dalam membangun kecerdasan moral seperti empati, hati nurani, kontrol diri, rasa hormat, kebaikan hati, toleransi, dan keadilan. Sesungguhnya kemerosotan moral masyarakat dapat diatasi jika pendidikan dapat memberikan kontribusi yang mengatasi masalah moral bangsa. Pendidikan 'di Indonesia seharusnya bukan hanya diarahkan untuk membangun manusia pintar saja tetapi bermoral. Beberapa teknik membangun kecerdasan moral siswa dijelaskan pada tulisan ini.
\end{abstract}

Kata Kunci: kecerdasan moral, empati, hati nurani, kontrol diri, rasa hormat, kebaikan hati, toleransi, keadilan.

\section{PENDAHULUAN}

Kalau kita kaji bahwa visi pendidikan nasional yang berbunyi "mencetak manusia Indonesia yang cerdas dan kompetitif" kemudian visi ini diterjemahkan dalam rencana strategis (renstra) Direktorat Jenderal Pendidikan Tinggi, yang disebut sebagai Higher Education Long Term Strategy (HELT) yaitu: 1) Meningkatkan Nations's competitiveness, 2) meningkatkan auotnomy dan 3) meningkatkan organizational Helts, dari visi dan renstra pendidikan ini dapat dikatakan hanya diarahkan untuk mencetak manusia Indonesia yang cerdas dan kompetitif, maka hanya dihasilkan manusia Indonesia yang pintar secara kognitif dan memiliki keahlian atau profesi yang andal atau dengan kata lain mampu bersaing dengan lainnya, akan tetapi kering dari moralitas.

Pendidikan tentunya diharapkan menghasilkan manusia Indonesia yang memiliki spirit moral seperti kejujuran, keadilan, bertanggungjawab, ikhlas dan tawakkal dalam menghadapi kehidupan. Spirit seperti itu tidak

\footnotetext{
${ }^{1}$ Rahayu Apriliaswati adalah dosen Jurusan Pendidikan Bahasa dan Seni FKIP-UNTAN Pontianak
} 
akan dicapai jika pendidikan hanya mengarahkan anak didik untuk menjadi pintar dan berkemampuan kompetitif. Spirit tersebut hanya dapat dicapai jika pendidikan diarahkan juga kepada pembekalan dan praksis moralitas yang baik. Jadi pendidikan Indonesia harus juga diarahkan untuk membekali anak didik dengan pendidikan bermoral tinggi sebagai basis spiritualitas Indonesia masa depan.

Memang sungguh-sungguh dirasakan betapa rendahnya kualitas kompetisi manusia Indonesia dalam relasinya dengan bangsa-bangsa lain. Indeks Pengembangan Manusia (IPM) Indonesia masih jauh dari harapan, yaitu berada dalam kisaran di atas 100 yang berarti di Asia Tenggara tergolong rendah jika dibandingkan dengan Singapura, Brunei, Malaysia, Thailand dan Filipina. Rendahnya IPM ini tentunya disebabkan oleh rendahnya kualitas pendidikan manusia Indonesia. Jadi tidak salah jika pemerintah melalui Departemen Pendidikan memerlukan pendidikan yang bertujuan untuk meningkatkan kecerdasan dan kompetisi bangsa.

Namun demikian, yang juga diperlukan berseiring dengan peningkatan kecerdasan dan kompetisi bangsa adalah peningkatan moralitas dalam mengelola kecerdasan dan kompetisi. Pintar saja tidak cukup. Kemampuan kompetisi saja juga tidak cukup. Maka selain cerdas, kompetitif juga harus memiliki kecerdasan moral.

Basis moralitas kiranya akan menghindarkan manusia Indonesia dari moralitas permissiveness yang sedang melanda negeri ini. Maraknya korupsi, penyalahgunaan kekuasaan, kekerasan, dan tindakan yang merugikan orang lain, masyarakat dan negara dewasa ini salah satu diantaranya ialah rendahnya kecerdasan moral. Makanya, agar Indonesia ke depan akan lebih baik maka tidak ada jalan lain kecuali pendidikan harus diarahkan untuk mendulang tiga domain sekaligus: cerdas, kompetitif dan spirit moralitas.

\section{Kecerdasan Moral}

Pintar dan cerdas saja tidaklah cukup menjadi jaminan keberhasilan seseorang. Ada nilai-nilai lain yang perlu dipegang teguh. Banyak fakta yang menunjukkan bahwa orang memiliki kecerdasan tinggi cenderung menyalahgunakan kehebatannya jika tak didukung faktor kecerdasan lain. Kecerdasan yang lebih" ini dinamakan kecerdasan moral (moral intelligence).

Kecerdasan moral merupakan "pusat kecerdasan" bagi seluruh manusia. Karena kecerdasan moral secara langsung mendasari kecerdasan manusia untuk berbuat sesuatu yang berguna. Kecerdasan moral memberikan hidup manusia memiliki tujuan. Tanpa kecerdasan moral, kita 
tidak dapat berbuat sesuatu dan peristiwa-peristiwa yang menjadi pengalaman jadi tidak berarti. Tanpa kecerdasan moral kita tidak akan tahu mengapa mengapa kita melakukan suatu pekerjaan dan apa yang harus dikerjakan.

Dengan kecerdasan moral manusia mampu memahami hal yang benar dan yang salah yaitu memiliki keyakinan etika yang kuat dan bertindak berdasarkan keyakinan tersebut, sehingga orang bersikap benar dan terhormat. Kecerdasan yang sangat penting ini mencakup sifat-sifat utama, seperti kemampuan untuk memahami penderitaan orang lain dan tidak bertindak jahat, mampu mengendalikan dorongan dan menunda pemuasan, mendengarkan dari perbagai pihak sebelum memberikan penilaian, menerima dan menghargai perbedaan, bisa memahami pilihan yang tidak etis, dapat berempati, memperjuangkan keadilan, dan menunjukkan kasih sayang, dan rasa hormat terhadap orang lain.

Banyak orang saat ini semakin tenggelam dalam persoalan yang serius karena mereka tidak pernah mempelajari kecerdasan moral. Dengan naluri yang lemah, control diri yang rapuh, kepekaan moral yang kurang, dan keyakinan yang salah, membuat orang-orang mengalami hambatan. Meski penyebab merosotnya moralitas sangatlah kompleks, terdapat fakta yang tidak dapat dipungkiri yaitu lingkungan keluarga, sekolah dan masyarakat serta kemajuan teknologi yang dahsyat.

\section{Tujuh Kecerdasan Moral Utama yang perlu dibangun pada diri siswa}

Kecerdasan moral terbangun dari tujuh kebajikan utama yaitu empati, hati nurani, kontrol diri, rasa hormat, kebaikan hati, toleransi, dan keadilan yang membantu anak menghadapi tantangan dan tekanan etika yang tidak dapat dihindarkan dalam kehidupan kelak. Kebajikan-kebajikan tersebut akan melindungi diri dari agar tetap berada di jalan yang benar dan membantunya agar selalu bermoral dalam bertindak. Semua itu dapat diajarkan, dicontohkan dan disadarkan serta didorong sehingga dapat tercapai. Tujuh kebajikan utama yang akan menjaga sikap baik seumur hidup pada diri seseorang adalah empati, hati nurani, kontrol diri, rasa hormat, kebaikan hati, toleransi, dan keadilan.

Empati merupakan inti emosi moral yang membantu seseorang memahami perasaan orang lain. Kebajikan ini membuat seseorang menjadi peka terhadap kebutuhan dan perasaan orang lain, mendorongnya menolong orang lain yang memerlukan bantuan, serta menuntutnya memperlakukan orang dengan kasih sayang. Emosi moral yang kuat mendorong seseorang bertindak benar karena ia bisa melihat kesusahan orang lain sehingga 
mencegahnya melakukan tindakan yang dapat melukai orang lain. Seseorang dengan empati yang baik dapat menunjukkan perilaku sebagai berikut:

- Menunjukkan kepekaan sosial; memahami perasaan orang lain

- Menunjukkan kepekaan terhadap kebutuhan orang lain

- Memahami orang lain secara tepat dari sikap tubuh, bahasa tubuh, ekspresi wajah, dan nada suara.

- Memahami ekspresi yang ditunjukkan orang lain dan memberi reaksi tepat.

- Menunjukkan kepedulian ketika orang lain diperlakukan dengan tidak adil.

Hati nurani adalah suara hati yang membantu seseorang memilih jalan yang benar daripada jalan yang salah serta tetap berada di jalur yang bermoral, membuat dirinya merasa bersalah ketika menyimpang dari jalur yang semestinya. Kebajikan ini membentengi seseorang dari pengaruh buruk dan membuatnya mampu bertindak benar meskipun tergoda untuk melakukan hal yang sebaliknya. Kebajikan ini merupakan fondasi bagi perkembangan sifat jujur, tanggung jawab, dan integritas tinggi. Ciri-ciri seseorang dengan hati nurani yang baik seperti:

- Mengaku salah dan minta maaf.

- Jujur dan kata-katanya bisa dipercaya.

- Tidak perlu diingatkan untuk bersikap benar.

- Tahu konsekwensi perbuatannya tidak benar.

- Tidak menimpakan kesalahannya pada orang lain.

- Merasa bersalah dan malu atas perbuatan buruknya.

- Bersikap baik meskipun ada tekanan untuk berbuat sebaliknya.

- Tahu bagaimana cara memperbaiki yang salah.

Kontrol diri membantu seseorang menahan dorongan dari dalam dirinya dan berpikir sebelum bertindak, sehingga ia melakukan hal yang benar, dan kecil kemungkinan mengambil tindakan yang akan menimbulkan akibat buruk. Kebajikan ini membantu seseorang menjadi mandiri karena ia tahu dirinya bisa mengendalikan tindakannya sendiri. Sifat ini mengembangkan sikap murah hati dan baik hati karena mampu menyingkirkan keinginan memuaskan diri serta merangsang kesadaran mementingkan orang lain. Seseorang dengan kontrol diri yang baik ditunjukkan melalui perilakunya sebagi berikut:

- Jarang menyela atau melontarkan jawaban atau pertanyaan tanpa berpikir terlebih dahulu.

- Menunggu giliran dan tidak memotong antrian.

- Mudah tenang kembali ketika marah, frustrasi, atau gembira. 
- Jarang meledak-ledak, marah-marah, atau lepas kendali.

- Menahan diri untuk tidak melakukan agresi fisik.

- Tidak ceroboh.

- Sabar menunggu.

- Tidak perlu diingatkan, diperintahkan, atau diminta bersikap baik.

Rasa hormat mendorong seseorang bersikap baik dan menghormati orang lain. Kebajikan ini mengarahkan seseorang pada memperlakukan orang lain sebagaimana ia ingin orang lain memperlakukan dirinya, sehingga mencegah seseorang bertindak kasar, tidak adil, dan bersikap memusuhi. Jika seseorang terbiasa bersikap hormat terhadap orang lain, ia akan memperhatikan hak-hak serta perasaan orang lain, akibatnya ia juga akan menghormati dirinya sendiri. Orang dengan rasa hormat yang baik adalah:

- Memperlakukan orang lain dengan hormat tanpa membedakan usia, agama, budaya, gender.

- Berbicara dengan kata-kata dan bahasa tubuh yang sopan.

- Tidak mau bergosip.

- Menghargai diri sendiri.

- Menghargai privasi orang lain.

- Menerima ide orang lain dengan tangan terbuka dan tidak menyela pembicaraan.

Kebaikan hati membantu seseorang mampu menunjukkan kepeduliaannya terhadap kesejahteraan dan perasaan orang lain. Dengan mengembangkan kebijakan ini, seseorang lebih belas kasih dan tidak terlalu mementingkan diri sendiri, serta menyadari perbuatan baik sebagai tindakan yang benar. Kebaikan hati membuat seseorang lebih banyak memikirkan kebutuhan orang lain, menunjukkan kepedulian, memberi bantuan kepada orang yang membutuhkan, serta melindungi mereka yang kesulitan atau kesakitan. Beberapa ciri-ciri sifat orang-orang dengan kebaikan hati yang kuat adalah sebagai berikut:

- Mengungkapkan komentar yang baik dan membangun.

- Peduli terhadap orang yang diperlakukan tidak adil.

- Memperlakukan makhluk ciptaanNya dengan baik.

- Berbagi, membantu, dan menghibur orang lain tanpa mengharapkan balasan.

- Suka melakukan sesuatu yang membuat orang lain senang.

Toleransi membuat seseorang mampu menghargai perbedaan kualitas dalam diri orang lain tanpa membedakan suku, gender, penampilan , budaya, kepercayaan, kemampuan. Kebajikan ini membuat seseorang memperlakukan orang lain dengan baik dan penuh pengertian, menentang 
permusuhan, kekejaman, kefanatikan, serta menghargai orang-orang berdasarkan karakter mereka.

Perilaku orang yang toleransinya tinggi dapat digambarkan sebagai berikut:

- Bertoleransi terhadap orang lain tanpa membedakan usia, budaya, agama atau gender.

- Menghormati orang tua atau orang-orang yang harus dihargai.

- Menunjukkan rasa tidak suka jika ada orang lain dihina dan direndahkan.

- Menghindari gurauan yang merendahkan seseorang.

- Bangga terhadap tradisi budayanya.

- Ramah kepada siapa saja.

- Memusatkan pada hal-hal yang positif pada orang lain.

- Tidak menilai atau membuat stereotipe orang lain.

Keadilan menuntun seseorang agar memperlakukan orang lain dengan baik, tidak memihak, dan adil, sehingga ia mematuhi aturan, mau bergiliran dan berbagi, serta mendengar semua pihak secara terbuka sebelum memberi penilaian apapun. Karena kebajikan ini meningkatkan kepekaan moral anak, ia pun akan terdorong membela pihak yang diperlakukan secara tidak adil dan menuntut agar semua orang tanpa pandang suku, bangsa, budaya, status ekonomi, kemampuan, atau keyakinan diperlakukan secara setara.

Seseorang yang memilki rasa keadilan yang kuat adalah:

- Senang melayani orang lain.

- Menunggu giliran dengan sabar.

- Tidak asal menyalahkan orang lain.

- Berkompromi.

- Berpikiran terbuka.

- Mau berbagi.

- Memecahkan masalah dengan damai dan adil.

- Mematuhi aturan.

- Memperhatikan hak-hak orang lain.

Teknik Mengembangkan Kecerdasan Moral dalam Pembelajaran Bahasa di Sekolah

Mengembangkan kecerdasan moral terutama pada tujuh sifat utama tersebut diatas perlu waktu, komitmen dan kesabaran bagi seorang pendidik. Pengembangan kecerdasan moral bukanlah hanya tanggung jawab guru PPKN atau Agama tapi merupakan tanggung jawab semua guru bidang studi termasuk bidang studi bahasa. Tujuan utama dalam mengembangkan kecerdasan moral pada siswa adalah agar mereka semakin lama semakin 
tidak tergantung lagi pada bimbingan moral guru dengan cara menerapkan prinsip-prinsip moral tersebut dalam kehidupan mereka sehari-hari dan menjadikan prinsip moral tersebut dalam kehidupan mereka. Hal ini dapat tercapai jika guru secara terus menerus menekankan pentingnya kebajikan moral dan para siswa berulang-ulang mempraktekkan prilaku bermoral tersebut karena kebiasaanlah yang membentuk diri manusia. Dengan mengajarkan secara ringkas, konsisten, dan terus menerus, para siswa akan berhasil menguasai kebajikan-kebajikan tersebut.

Berikut ini adalah beberapa contoh teknik melatih atau mengembangkan kecerdasan moral:

\section{Teknik mengembangkan empati}

Ada tiga penekanan dalam membangun empati yaitu membangkitkan kesadaran dan perbendaharaan ungkapan emosi, meningkatkan kepekaan terhadap perasaan orang lain serta mengembangkan empati terhadap sudut pandang orang lain.

Beberapa teknik membangun empati dapat dilakukan sebagai berikut:

a. Membangkitkan kesadaran dan perbendaharaan ungkapan emosi

Untuk meningkatkan kosa kata ungkapan emosi, sering-seringlah guru mengungkapkan pertanyaan yang membantu siswa memahami perasaannya dan mengungkapkan perasaan seperti yang ada pada tabel berikut ini:

Tabel 1: Membangkitkan Kesadaran dan Perbendaharaan Ungkapan Emosi

\begin{tabular}{|c|c|}
\hline Mengajukan Pertanyaan tentang perasaan & swa me \\
\hline $\begin{array}{l}\text { "Sepertinya kamu sedang tegang, } \\
\text { bingung, cemas,sedih marah, keal, } \\
\text { gembira) ada apa?/kenapa ya?" } \\
\text { "Bagaimana perasaanmu?/menurutmu } \\
\text { bagaimana perasaan mu?" }\end{array}$ & $\begin{array}{l}\text { Menunjukkan ekspresi sedih misalnya } \\
\text { menitikkan air mata ketika sedih atau } \\
\text { tertawa ketika bergembira. Guru dapat } \\
\text { melakukannya melalui drama, role play, } \\
\text { pantomin, bacan narratif, puisi, lagu. }\end{array}$ \\
\hline $\begin{array}{l}\text { Melakukan permainan dengan mencari } \\
\text { huruf yang dapat mengungkapkan } \\
\text { perasaan misalnyaG= gembira; } \mathrm{B}= \\
\text { berani; } \mathrm{T}=\text { tenang; } \mathrm{S}=\text { sabar; } \mathrm{K}=\text { kasihan, } \\
\text { dst }\end{array}$ & $\begin{array}{l}\text { Berusaha menghibur orang lain yang } \\
\text { susah melalui drama, role play. }\end{array}$ \\
\hline $\begin{array}{l}\text { Meminta siswa mengungkapkan } \\
\text { perasaannya seperti apa yang membuat } \\
\text { kalian paling gembira minggu ini? }\end{array}$ & $\begin{array}{l}\text { Meringis me } \\
\text { pantomin }\end{array}$ \\
\hline $\begin{array}{l}\text { Membuat kartu perasaan } n \\
\text { masing-masing kartu bertuliskan } \\
\text { macam perasaan seperti bangga } \\
\text { senang dst kemudian siswa }\end{array}$ & $\begin{array}{l}\text { resi gembira misalnya } \\
\text { atau puisi yang } \\
\text { egembiraan }\end{array}$ \\
\hline
\end{tabular}




\begin{tabular}{|l|l|l|l|}
\hline $\begin{array}{l}\text { mencocokkan kartu dengan gambar- } \\
\text { gambar yang ada dilayar LCD. Kemudian } \\
\text { tanyakan perasaan yang mana yang ada } \\
\text { pada gambar dan kartu yang paling sesuai } \\
\text { dengan perasaan mereka. }\end{array}$ & & & \\
& & & \\
Mencari sinonim kata-kata yang \\
mengungkapkan perasaan (marah, sebel, \\
kesal) atau antonim (tenang, damai, \\
tentram) kemudian kapan perasaan itu \\
terjadi, sebutkan bagian tubuh yang \\
berpengaruh pada perasaan itu dan \\
memperagakan dan duka melalui \\
tersebut.
\end{tabular}

\section{b. Meningkatkan Kepekaan terhadap Perasaan Orang Lain}

Berikut ini beberapa contoh cara melatih kepekaan terhadap orang lain:

1).Melakukan permainan tebak perasaan. Misalnya siswa diminta memperagakan perasaannya saat itu kemudian siswa yang lain menebaknya.

2). Membuat komik mengungkapkan perasaan dengan menggunting gambargambar yang ada pada koran atau majalah yang menggambarkan ekpresi perasaan kemudian meminta anak menuliskan kira-kira kata-kata apa yang diucapkan orang yang ada pada gambar-gambar tersebut.

3). Membaca Perasaan. Kegiatan ini membantu siswa mengenali suasana hati melalui nada suara. Guru membacakan cerita apa saja dengan variasi suara yang berbeda-beda (Bosan, senang, lelah, sedih, marah) dan meminta siswa untuk menebak nada tersebut.

4). Melatih membaca perasaan melalui non verbal. Siswa menonton TV dengan tanpa suara kemudian siswa diminta untuk menebak perasaan dari tokoh di TV dengan melihat perilaku non verbal yang dilakukan mereka untuk mengekspresikan perasaannya. Misalnya orang yang tegang dengan mengedip-ngedipkan matanya, memilin rambut, mengepal tangan. Orang yang bosan mengalihkan pandangan atau menjauhi pembicaraan. Orang yang tertarik biasanya mengangguk-angguk, mendekat pada si pembicara, tersenyum, mengangkat alis, dst.

\section{c. Mengembangkan Empati terhadap Sudut Pandang Orang Lain.}

Untuk mengembangkan siswa apa yang dirasakan atau dipikirkan orang lain, teknik bermain peran dapat dilakukan. Misalnya siswa diminta berperan agar merasakan apa yang dirasakan orang lain misalnya bermain peran menjadi 
seorang kakak, ibu, adik, guru, orang buta, orang lumpuh, orang minta-minta dst. Teknik bermain peran juga dapat melatih anak mengidentifikasikan perasaan orang lain dengan menyuruhnya membayangkan apa yang dirasakan orang tersebut dalam kondisi tertentu dan melatih mereka menempatkan dirinya pada posisi orang lain serta merasakan bagaimana rasanya mengalami perasaan yang dirasakan orang lain.

\section{Teknik Mengembangkan Hati Nurani}

Hati nurani adalah suara hati yang kuat yang membantu kita membedakan hal yang benar dan yang salah. Seseorang yang mempunyai hati nurani dapat bertindak sesuai dengan apa yang mereka anggap benar, mematuhi peraturan walaupun tidak diawasi, tidak melakukan perbuatan buruk karena mereka tahu bahwa perbuatan itu salah. Guru dapat mengembangkan hati nurani para siswa melalui kegiatan seperti berikut ini:

1). Memberikan bacaan-bacaan, film, cerita dongeng yang memuat kebajikan-kebajikan kepada siswa.

2). Meminta anak membuat daftar karakteristik suatu kebajikan berikut contoh-contohnya. Misalnya perilaku jujur: tidak mencontek, berkata jujur, menepati janji, mengakui kesalahan, dst.

3). Mengajarkan kata-kata yang berkaitan dengan suatu kebajikan seperti "aku tidak boleh datang terlambat", "kita harus berkata jujur", "aku tak akan menyerah", "aku harus segera menolongnya", "aku akan memenuhi janjiku", dst.

4). Membuat kliping kebajikan.

5). Memerankan suatu kebajikan.

\section{Teknik Mengembangkan Kontrol Diri}

Kontrol diri yaitu dapat mengendalikan pikiran dan tindakan agar dapat menahan dorongan dari dalam maupun dari luar sehingga dapat bertindak dengan benar. Ada tiga langkah yang dapat dilakukan untuk mengembangkan kontrol diri siswa. Langkah pertama adalah memberikan contoh kontrol diri dan menjadikan hal tersebut sebagai prioritas. Langkah kedua yaitu mendorong siswa agar memotivasi diri. Langkah ketiga yaitu mengajarkan cara berpikir sebelum bertindak. Strategi yang dapat dilakukan yaitu:

1). Belajar mengungkapkan dengan kata-kata. Misalnya meminta siswa mencari kata-kata yang dapat menunjukkan kepada orang lain bahwa mereka benar-benar marah. Misalnya: marah, kesal, sebel, tegang, tersinggung, sakit hati, dst. Meminta mereka menggunakan kata-kata tersebut ketika sedang marah. Misalnya "Sepertinya kamu sedang kesal", atau "Kelihatannya kamu tersinggung". 
2). Mempelajari tanda-tanda amarah. Misalnya nada suara yang meninggi, wajah terasa panas dan memerah, telapak tangan mengepal, jantung berdegup, mulut terasa kering, napas terengah-engah. Mereka diminta membuktikan tanda-tanda tersebut ketika marah. Dengan mengetahui tanda-tanda amarah mereka akan dapat menenangkan diri dan belajar mengatur perilakunya.

3). Menenangkan diri dengan berbicara dalam hati. Mengajarkan siswa ungkapan kata-kata sederhana yang positif seperti:"tetap tenang", "tetap terkendali", "aku bisa mengatasinya", "tarik nafas dalam-dalam", dan bantu mereka untuk menggunakannya setiap hari.

4). Mengajarkan teknik pernafasan untuk mengontrol emosi.

5). Mengubah kata "aku" menjadi "kamu". Agar menjauhkan siswa dari kontrol eksternal, gunakan kata "aku" menjadi "kamu" pada siswa. Misalnya: "kamu pasti bangga dengan hasil kerjamu" bukan ungkapan "aku bangga dengan hasil kerjamu".

6). Memuji tindakan siswa bukan memuji siswa. Misalnya: "Baik sekali pertanyaan yang kamu ajukan tadi" bukan " Kamu anak yang pandai".

\section{Teknik Mengembangkan Rasa Hormat}

Rasa hormat merupakan kebajikan yang mendasari tata krama. Kita seharusnya memperlakukan orang lain sebagaimana kita mengharapkan orang lain memperlakukan kita. Seseorang yang sehari-hari menunjukkan rasa hormat cenderung lebih menghargai hak orang lain, memandang orang dengan positif dan penuh perhatian. Dengan mendiskusikan dan mempraktekkan perkataan dan tindakan contoh orang yang memiliki rasa hormat melalui bermain drama, bermain peran atau bacaan narratif atau membuat daftar sikap-sikap hormat pada pembelajaran bahasa seperti berikut ini:

Contoh-contoh ungkapan kata-kata, tindakan dan tata krama rasa hormat:

\begin{tabular}{|l|l|l|}
\hline \multicolumn{1}{|c|}{ Kata-kata sopan } & \multicolumn{1}{c|}{ Tindakan rasa hormat } & \multicolumn{1}{c|}{ Tata krama } \\
\hline Maaf... & Menunggu hingga orang lain & Menyapa (tersenyum dan \\
Permisi... & berbicara. & menatap lawan bicara. \\
Terima kasih... & Membuka pintu bagi orang & Menjabat tangan. \\
Tolong... & tua, anak kecil, wanita. & Mengucapkan salam. \\
"Pendapatmu yang bagus". & Tidak membantah. & Memperkenalkan diri. \\
"Saya bisa mengerti kalau anda & Menjaga lingkungan. & Sopan pada orang yang \\
tidak sependapat" Bolehkah & Mendengar tanpa menyela & lebih tua, \\
saya...? & pembicaraan. & Mengetahui etika \\
& Mematuhi guru dan orang tua. & percakapan, bertamu, \\
& & bertelepon, di meja \\
& & makan dsb. \\
\hline
\end{tabular}




\section{Strategi Mengembangkan Kebaikan Hati}

Kebaikan hati adalah kemampuan menunjukkan kepedulian terhadap kesejahteraan dan perasaan orang lain. Kebaikan hatilah yang menjadikan manusia beradab, berperikemanusian, dan bermoral. Beberapa strategi yang dapat dilakukan guru antara lain:

1). Menunjukkan kebaikan hati pada siswa. Siswa akan banyak belajar moralitas dengan meniru perbuatan orang dewasa seperti orang tua dan guru. Oleh karena kebaikan kata-kata dan perbuatan orang tua dan guru akan ditiru para siswa.

2). Mengharapkan kebaikan hati yaitu dengan mengungkapkan berulangulang bahwa semua orang harus diperlakukan dengan baik.

3). Mengajarkan makna kebaikan hati. Salah satu cara menumbuhkan kebaikan hati adalah membantu siswa membedakan antara kata-kata yang membuat orang lain senang atau sedih dengan meminta siswa membuat daftar kata-kata tersebut seperti: "Apakah semuanya baik baik saja?", "Saya siap membantumu", "Terima kasih atas bantuanmu", "Semoga lekas sembuh", "Semoga berhasil", "Selamat bekerja", "Mudah-mudahan kamu merasa lebih baik", "Semoga kamu berhasil", dsb.

4). Menunjukkan bentuk perbuatan baik. Aktivitas ini dapat dilakukan kapan saja bersama siswa. Guru dapat memberikan tugas agar siswa memperhatikan perbuatan baik dan menceritakan hasil observasinya di kelas. Misalnya memberikan sedekah pada orang miskin kemudian anak diminta melihat reaksi orang tersebut lalu diceritakan di kelas.

5). Memberikan suatu kasus kehidupan dan meminta para siswa mencari solusinya melalui tugas kelompok. Misalnya isi tas seorang nenek tumpah didalam oplet yang baru berjalan. Apa yang harus kamu lakukan sebagai penumpang oplet?

\section{Strategi Membangun toleransi}

Kata kunci utama toleransi adalah membantu siswa bersosialisasi didunia yang diwarnai berbagai perbedaan. Ada tiga langkah yang dapat diambil untuk membangun toleransi siswa yaitu: mencontohkan dan menumbuhkan toleransi, menumbuhkan appresiasi terhadap perbedaan, serta menentang streotipe dan tidak berprasangka. Strategi-strategi berikut ini dapat dilakukan guru:

1) Melalui permainan "siapakah aku". Siswa diminta menyebutkan pernyataan yang positif tentang dirinya diminta melakukan kualitas positif mereka tersebut dalam satu minggu lalu menceritakannya di kelas. 
2). Melalui permainan "siapa dia". Siswa diminta menyebutkan kualitas positif dari teman-temannya dan memberikan contoh perbuatan positif temannya yang diamati dalam waktu satu minggu lalu menceritakannya di kelas.

3). Untuk menerima dan menghargai perbedaan pandangan orang lain maka guru dapat memperkenalkan berbagai tradisi budaya, musik, makanan, cerita rakyat dari berbagai kelompok multikultur melaui kegiatan membaca.

\section{Strategi mengembangkan sifat adil}

Keadilan adalah sesuatu yang mendorong manusia untuk berpikiran terbuka dan jujur serta bertindak dengan benar. Sifat-sifat keadilan mendorong kita untuk mematuhi aturan, bergiliran, berbagi, dan mendengarkan semua pihak untuk secara terbuka sebelum memberi penilaian.

Strategi berikut ini dapat membantu guru dalam mengembangkan sifat adil bagi para siswa:

1). Memilih topik berdasarkan minat dan bakat siswa dengan cara meminta siswa memilih sesuatu yang dikuasai dan disukainya.

2). Guru membantu siswa mencari informasi dan memecahkan masalah tentang topik yang dipilihnya.

3). Menghargai usaha mereka.

4). Memadukan kegiatan seperti membaca, menulis dan bercerita yang berisi pesan nilai keadilan.

\section{PENUTUP}

Tujuan pendidikan adalah anak mampu hidup dimasyarakat yang penuh persaingan dan keterbukaan di abad ke 21 ini. Untuk mampu beradaptasi dengan masyarakat, kecerdasan moral sangat memegang peranan yang penting. Untuk itu kecerdasan moral ini harus bangun pada diri siswa. Ada tujuh kebajikan utama yang seharusnya menjadikan perhatian para pendidik yaitu empati, nurani, kendali diri rasa hormat, kebaikan hati, toleransi dan adil. Dengan menginterasikan tujuh kecerdasan moral dalam pembelajaran bahasa, guru dapat membangun kecerdasan moral siswa baik melalui empat ketrampilan berbahasa seperti mendengar, berbicara, membaca dan menulis serta aspek kebahasaan lainnya seperti kosa kata, pengucapan, tata bahasa maupun melalui strategi-strategi pembelajarannya. 


\section{Daftar Bacaan}

Borba, Michele. 2008. Membangun Kecerdasan Moral (Tujuh Kebajikan Utama untuk Membentuk Anak Bermoral Tinggi). Jakarta: Gramedia Pustaka.

Nucci, Larry P dan Narvaez, Darcia. 2008. Handbook of Moral and Character Education. New York: Routledge.

Greene, John O. and Burleson, Brant R. 2003. Handbook of Communication and Social Interaction Skills. London: Lawrence Erlbaum Associates. 